\title{
Chilean experience using "Theranostics" for treating metastatic neuroendocrine tumors with [177Lu]Lu DOTA-
}

Received: 28 March, 2020

Accepted: 26 May, 2020

Published: 27 May, 2020

*Corresponding author: Horacio Amaral, Center for Nuclear Medicine \& PET/CT Positronmed, Julio Prado 714, Providencia. Postal code: 7501068, Santiago, Chile, E-mail: hamaral@positropharma.cl: hamaral@positronmed.cl

https://www.peertechz.com

Check for updates TATE

\author{
Horacio Amaral ${ }^{1,2 *}$, Rossana Pruzzo', René Fernández', \\ Vasko Kramer ${ }^{1,2}$, Cristian Soza-Ried ${ }^{1}$ and Irene Coudeu ${ }^{1}$ \\ ${ }^{1}$ Center for Nuclear Medicine \& PET/CT Positronmed, Julio Prado 714, Providencia. Postal code: \\ 7501068, Santiago, Chile \\ ${ }^{2}$ Positronpharma SA, 7500921 Providencia, Santiago, Julio Positronpharma SA, Rancagua 878, \\ 7500921 Providencia, Santiago, Chile
}

\begin{abstract}
Introduction: Well-differentiated, Neuroendocrine Tumors (NET) are highly heterogenic and slow-growing pathologies, characterized by unspecific symptomatology and elevated expression of somatostatin receptors (SSTR). Despite the high incidence of NETs, several patients are diagnosed in advance stages of the disease when surgery is insufficient to treat the pathology. Peptide receptor radionuclide therapy (PRRT) has emerged as a new state-of-the-art treatment for NET-patients in advanced stages.

Results: In this retrospective study, between 2004 and 2018 a total of 66 patients with advanced-stage-NETs, refractory to other therapies, were treated with [17'Lu]Lu DOTA TATE. At the end of the study, $56.1 \%$ of the patients were alive and the median overall survival for all patients in the study was 86.3 months. Patients that received doses $\geq 22.2 \mathrm{GBq}$ showed increased overall survival (OS) in comparison with patients that received doses $<22.2 \mathrm{GBq}(\mathrm{HR}, 0.168 ; 95 \% \mathrm{Cl} 0.12-0.99 ; \mathrm{p}<0.001)$, adjusted by gender. Likewise, patients that received doses $\geq 29.6 \mathrm{GBq}$ had an increased OS ( $\mathrm{HR}, 0.42 ; 95 \% \mathrm{Cl} 0.19-0.94, \mathrm{p}<0.05)$.
\end{abstract}

Conclusion: Although several studies have shown that PRRT is an effective alternative for advanced NET, patients in South America have no regular access to PRRT. Our study proves that $\left[{ }^{177} \mathrm{Lu}\right] \mathrm{Lu}$-DOTA-TATE effectively increases the survival of patients with metastatic NET and provides an excellent alternative in terms of costefficiency for South American countries.

\section{Introduction}

The worldwide incidence of neuroendocrine tumors (NETs) is rising [1-9]. NETs mainly affect the gastrointestinal tissue $[1-3,10]$, and are considered slowly progressing cancers characterized by a wide variety of unspecific symptoms with different levels of tumor differentiation and prognosis [11]. Unfortunately, the slow progression and the broad spectrum of clinical presentation of NETs lead to unawareness and late diagnose, resulting in limited therapeutic options for patients
$[2,3]$. Nevertheless, during the last decades, peptide receptor radionuclide therapy (PRRT) has emerged as a treatment option for patients with metastatic NET that exhibit high expression of somatostatin receptors (SSTR) [12]. SSTR bind somatostatin (SST), a paracrine 14 amino acid neuropeptide secreted by cells of the pancreas, the gastrointestinal tissue and the brain [13]. Thus, we can target SSTR-overexpressing cancer cells of middle or low grade neuroendocrine carcinomas (classified by the WHO as G1 and G2) with SST peptides analogues labelled with therapeutic radioisotopes such as yttrium-90 or lutetium-177. 
Although PRRT is widely used in a subgroup of advanced NETs $(\mathrm{G} 1 / \mathrm{G} 2, \mathrm{Ki}-67<20 \%)$, it is not a standard procedure in Chile and other countries in South America. For example, the public health system (Ricarte Soto law $\mathrm{N}^{0} 20.850$ ) only covers everolimus and sunitinib to treat patients with non-operable metastatic G1/G2-NETs [14]. In this retrospective analysis, we present data from 66 patients with metastatic NETs that have been treated with [ $\left.{ }^{177} \mathrm{Lu}\right] \mathrm{Lu}-\mathrm{DOTA}-\mathrm{TATE}$ between 01/2004 and 06/2018. All patients had histopathological confirmation of metastatic NETs with overexpression of SSTR-2, as confirmed by $\left[{ }^{68} \mathrm{Ga}\right] \mathrm{Ga}-\mathrm{DOTA}-\mathrm{TATE}$ PET/CT or [111 In]In-DTPA-[D-Phe1]Octreotid (OctreoScan ${ }^{\circledR}$ ) SPECT/CT. All patients were in palliative care without further treatment options and matched commonly accepted inclusion criteria [15].

\section{Results}

All patients were treated with $\left[{ }^{177} \mathrm{Lu}\right] \mathrm{Lu}-\mathrm{DOTA}-\mathrm{TATE}$ at PositronMed, and the retrospective study was approved by the regional ethics committee board (Servicio de Salud Metropolitano Oriente, permit number 20191203) and in accordance to the Declaration of Helsinki, Good Clinical Practices, and Chilean regulations. The survival was calculated using the Kaplan-Meier method and the survival functions between the different groups were done using the log-rank test. Our analysis showed that the median overall survival (OS) for all patients in the study was 86.3 months, and the 5-year survival rate was $55.29 \%$ (95\% CI, 40.9\%-67.5\%) (Figure $1 \mathrm{~A}) .83 .3 \%$ of the patients presented gastroenteropancreatic neuroendocrine tumors (GEP-NET). The median age at diagnosis was 53.98 years (range $13-79$ ), and $57.6 \%$ of the patients were male. Within the GEP-NET group, 58.8\% presented gastrointestinal tumors, $30.9 \%$ presented pancreatic tumors, and in $10.9 \%$ of the cases, the tumors were of rectal origin. Patients with NETs from other tissues than the gastroenteropancreatic tissue were registered as others. Patients with GEP-NET exhibited a higher OS than patients affected by other NETs types, but the number of patients in the others-NET group was rather low (9 patients). There was no statistical difference in OS between tumor grade ( $\mathrm{G} 1$ and G2), age, or gender, although we did observe that female had slightly higher OS (Figure 1B). To determine whether a certain cumulative dose of $\left[{ }^{177} \mathrm{Lu}\right] \mathrm{Lu}-$ DOTA-TATE could increase the OS, we grouped patients that received less than $22.2 \mathrm{GBq}$ (23 patients) and compared the OS to those that received $\geq 22.2 \mathrm{GBq}$ ( 43 patients). Patients that received a cumulative activity $\geq 22.2 \mathrm{GBq}$ had a significantly higher OS than patients that received $<22.2 \mathrm{GBq}(\mathrm{p}<0.001)$ (Figure 1C).

The Cox proportional hazard model, adjusted by gender, showed that patients receiving doses of $22.2 \mathrm{GBq}$ or more reduced by a $83 \%$ the expected hazard as compared to patients that received fewer doses (Hazard Ratio $(\mathrm{HR})=0.168$; 95\%CI $0.12-0.99 ; \mathrm{p}<0.001)$ at any given time during the study. When we analyzed the OS of female $(n=12)$ and male $(n=11)$ patients that received $<22.2 \mathrm{GBq}$, we observed that females had a median survival of 45.8 versus 19.7 in males ( $<<0.05$; HR=0.352; 95\%CI, 0.15-0.83) (Figure 1D). However, this difference was not evident in the group receiving $\geq 22.2 \mathrm{GBq}$ (Figure $1 \mathrm{E}$ ).
Our data further indicate that patients that received over 29.6 GBq had a higher OS than patients that received less $(\mathrm{p}<0.05)$ (Figure 1F) (HR, 0.42; 95\%CI 0.19-0.94).

\section{Discussion}

This retrospective study summarizes our experience with the Theranostic agent $\left.{ }^{177} \mathrm{Lu}\right] \mathrm{Lu}-\mathrm{DOTA}-\mathrm{TATE}$ to treat patients affected by NET (G1 or G2). Our results support the notion that patients with advanced metastatic NETs benefit from PRRT therapy with [ $\left.{ }^{177} \mathrm{Lu}\right] \mathrm{Lu}-\mathrm{DOTA}-\mathrm{TATE}$. The median survival for G1 and G2 patients is 124 and 64 months, respectively. However, G1/G2 patients with advanced disease and distant metastasis show a median survival of only 33 months [2]. Our results showed that patients treated with $\left[{ }^{177} \mathrm{Lu}\right] \mathrm{Lu}-\mathrm{DOTA}-\mathrm{TATE}$ had a median survival of 87.6 months with no statistical differences in median survival between patients with G1 or G2, although we had only a few cases of G1 (8 cases).

The median survival improved significantly in patients that received a cumulative dose of $\geq 22.2 \mathrm{GBq}$ of [ $\left.{ }^{177} \mathrm{Lu}\right] \mathrm{Lu}-\mathrm{DOTA}-$ TATE. In fact, for patients that received a cumulative dose of $\geq 22.2 \mathrm{GBq}$ the estimated median survival was not reached, whereas for patients that received a cumulative dose $<22.2 \mathrm{GBq}$, the median survival was $\mathbf{3 2 . 2}$ months. If a therapeutic response by imaging or based on biomarkers can be observed following [ $\left.{ }^{177} \mathrm{Lu}\right] \mathrm{Lu}-\mathrm{DOTA}-\mathrm{TATE}$ treatment [16-18], a further increase of the cumulative dose should also increase the survival time. Not surprisingly, the median survival time of patients that received a cumulative dose of $\geq 29.6 \mathrm{GBq}$ was also not reached, whereas patients that received a cumulative dose $<29.6 \mathrm{GBq}$ showed a median survival time of 45.8 months. Cross-sectional imaging, such as CT, is considered the standard follow-up analysis. However, levels above the normal upper limit of chromogranin A (CgA) and alkaline phosphatase (ALP) have been associated with shorter survival in patients with metastatic NETs [19]. Unfortunately, CgA was not initially available in the country, which made it impossible to measure this biomarker in all our patients. Furthermore, since $\mathrm{CD} 3+$ cell infiltration and levels of circulating regulatory $\mathrm{T}$ cells are associated with recurrencefree survival and prognosis, it would be interesting to include these biomarkers in future studies $[20,21]$.

As gender affect OS [2,16], we analyzed the difference between females and males. We noticed, that in the group that received a cumulative dose $<22.2 \mathrm{GBq}$, females showed a significantly higher median survival than males. However, the difference in median survival between gender disappeared in patients that received a cumulative dose of $\geq 22.2 \mathrm{GBq}$.

Side-effects of PRRT with $\left.{ }^{[177} \mathrm{Lu}\right] \mathrm{Lu}-\mathrm{DOTA}-\mathrm{TATE}$ may include myelotoxicity or nephrotoxicity due to the relatively high update in kidneys [22]. Although the risk of nephrotoxicity is rather low and cases are rare, the risk can be further reduced by co-administration of renal-protective agents [12]. Hematological toxicity usually occurs 4 to 6 weeks after therapy and is usually mild and reversible. Therefore, it is crucial to select patients with relatively normal bone marrow and renal functions to reduce the occurrence of severe side effects. In our study population, we observed in $13 \%$ of

Citation: Amaral H, Pruzzo R, Fernández R, Kramer V, Ried CS, et al. (2020) Chilean experience using "Theranostics" for treating metastatic neuroendocrine tumors with [ ${ }^{177}$ Lu]Lu DOTA-TATE. Arch Clin Gastroenterol 6(2): 036-040. DOI: https://dx.doi.org/10.17352/2455-2283.000076 
A

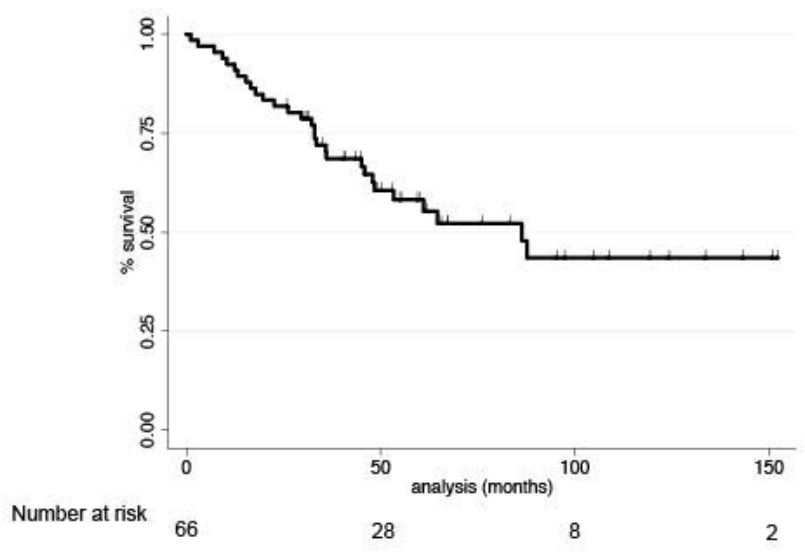

C

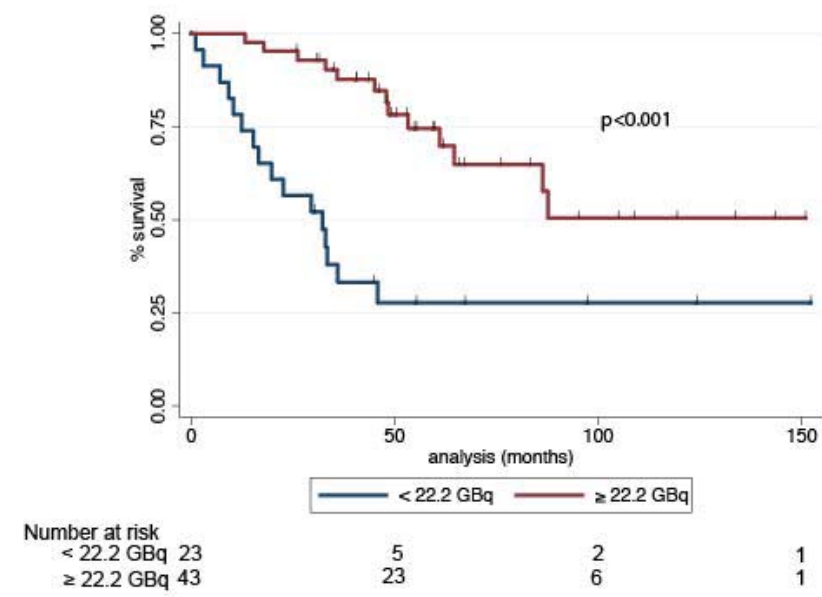

$\mathrm{E}$

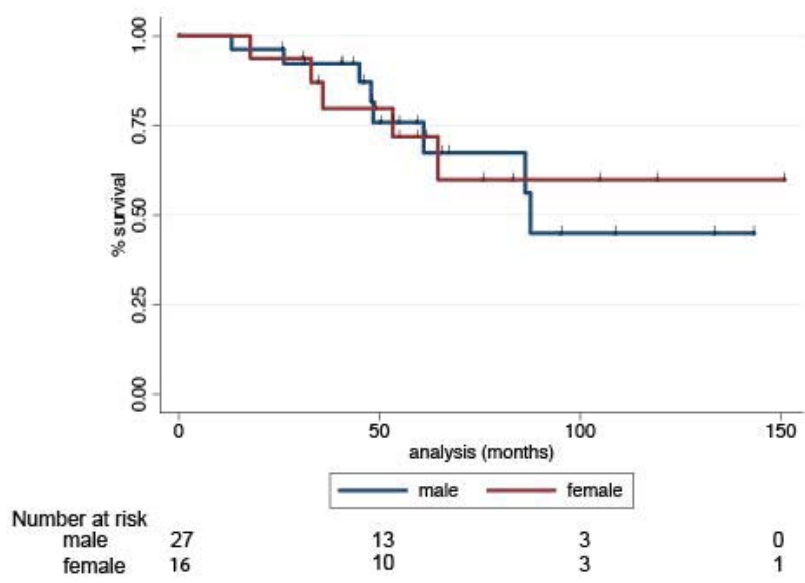

B

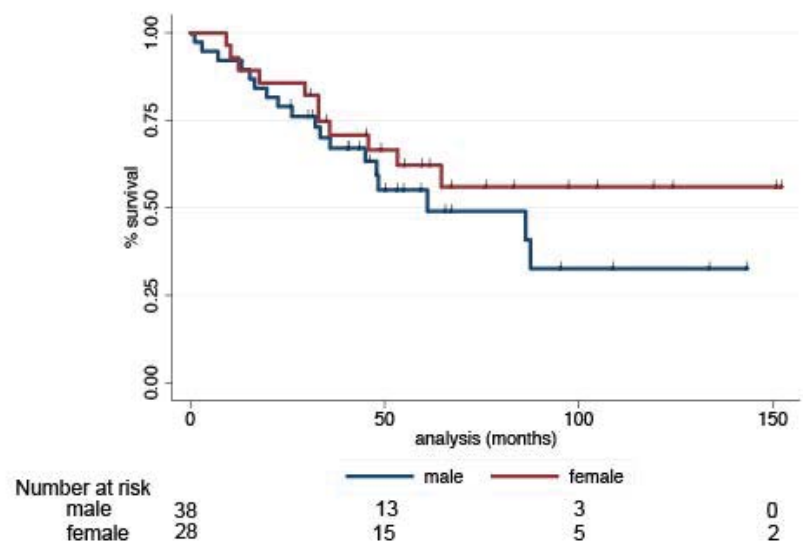

D

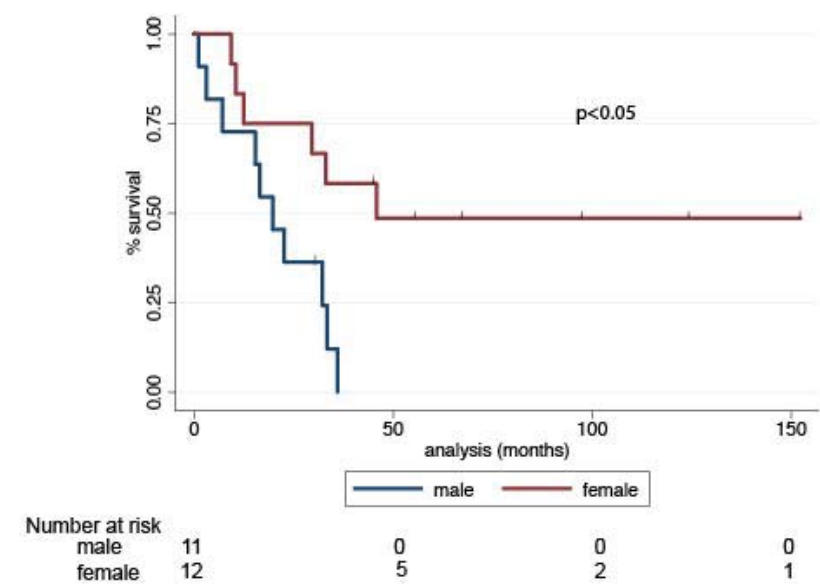

$\mathrm{F}$

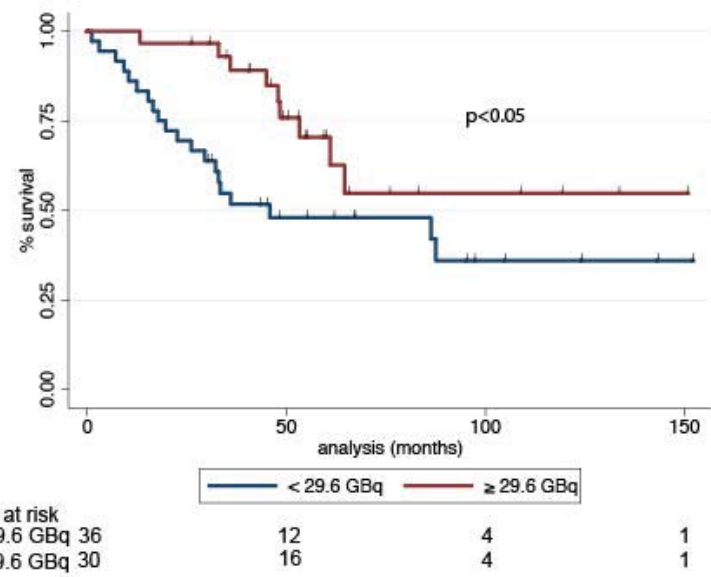

Figure 1: Kaplan-Meier survival curves. (A) Patients analyzed retrospectively $(n=66)$ showed a median overall survival of 86.3 months. (B) Comparation between male (blue line) and female patients (red line). At the bottom of every Kaplan-Meier curve is indicated the number of patients at risk over time.

(C) Comparation between patients that received total doses $<22.2 \mathrm{GBq}$ (blue line) and patients that received $\geq 22.2 \mathrm{GBq}$ (red line) (Log Rank test $p<0.001$ ). (D) Comparation between male (blue line) and female (red line) patients that received total doses $<22.2 \mathrm{GBq}$ and patients that received (Log Rank test $p<0.05$ ). (E) Comparation between male (blue line) and female (red line) patients that received total doses $\geq 22.2 \mathrm{GBq}$ (Log Rank test $p=0.92$ ). ( $F$ ) Comparation between patients that received total doses $<29.6 \mathrm{GBq}$ (blue line) and patients that received $\geq 29.6 \mathrm{GBq}$ (red line) (Log Rank test $p<0.05$ ). At the bottom of every Kaplan-Meier curve is indicated the number of patients at risk over time.

Citation: Amaral H, Pruzzo R, Fernández R, Kramer V, Ried CS, et al. (2020) Chilean experience using "Theranostics" for treating metastatic neuroendocrine tumors with [177Lu]Lu DOTA-TATE. Arch Clin Gastroenterol 6(2): 036-040. DOI: https://dx.doi.org/10.17352/2455-2283.000076 
the patients a carcinoid syndrome following treatment with diarrhea, vomiting, increase of weight, hepatomegaly and bone pain as the most prevalent side effects. Nevertheless, these were transitory and patients improved within a short period of time after the therapy.

A limitation of our study is the fact that patients were referred from different medical institutions throughout the country. As a consequence, clinical follow-up was not available for all patients due to the limited availability of imaging or access to their local health institution.

Our results have important implications: firstly, we provide data for more than 14 years of PRRT with $\left.{ }^{177} \mathrm{Lu}\right] \mathrm{Lu}-$ DOTA-TATE to treat patients affected by metastatic NETs, contributing to the recently published register of NET patients in Chile [23]. The Chilean and Argentinian registers show a high incidence of GEP-NETs, which is in line with our study and others $[1,24]$. However, this is not the case for the Brazilian population in which GEP-NET is the second most frequent NET [25]. Therefore, it is important to characterize our populations if we want to design strategies for early detection and improve treatments outcomes. Secondly, Pinto et al. reported a high proportion of metastatic patients in the Chilean register. The study proposed different factors such as the bias of the register itself (led by an oncologist or oncologists), late diagnose and economic factors that limit the access to preventive care early diagnosis and treatment [23]. Our study shows that, patients with access to $\left[{ }^{177} \mathrm{Lu}\right] \mathrm{Lu}-\mathrm{DOTA}$-TATE, may benefit from increased survival and quality of life, as other studies have also shown [16,26-29]. Thirdly, the access and cost of the treatment depend on several factors such as availability, treatment duration, number of doses required, individual patient conditions and reimbursement. Moreover, since NET is a rare disease and different diagnostic and therapeutic protocols are applied depending on the individual condition of the patient (personalized medicine), the experience of the medical staff is of utmost importance. Today, only a few centers have the necessary experience to treat NET patients and administer PRRT treatments, highlighting the urgent need of suitable training programs for the Theranostic field.

\section{Conclusion}

Although the availability of PRRT is limited to a few specialized centers, our results suggest that $\left.{ }^{177} \mathrm{Lu}\right] \mathrm{Lu}-\mathrm{DOTA}-$ TATE is an excellent alternative in term of cost-effectiveness, especially considering the current situation in Chile and other South American countries.

\section{Conflict of interest}

All authors contributed to the study conception and design. Amaral H, Pruzzo R, Fernández R, and Coudeu I treated the patients, performed the PET/CT ${ }^{18} \mathrm{~F}-\mathrm{FDG}$ scans and collected the data. All the authors analyzed the data and the first draft of the manuscript was written by Cristian Soza-Ried and Horacio Amaral. All authors commented on previous versions of the manuscript. All authors read and approved the final manuscript.

\section{References}

1. Modlin IM, Oberg K, Chung DC, Jensen RT, de Herder WW, et al. (2008) Gastroenteropancreatic neuroendocrine tumours. Lancet Oncol 9: 61-72. Link: https://bit.ly/2ZBblrc

2. Yao JC, Hassan M, Phan A, Dagohoy C, Leary C, et al. (2008) One hundred years after "carcinoid": epidemiology of and prognostic factors for neuroendocrine tumors in 35,825 cases in the United States. J Clin Oncol 26: 3063-3072. Link: https://bit.ly/3c7WEE1

3. Hallet J, Law CH, Cukier M, Saskin R, Liu N, et al. (2015) Exploring the rising incidence of neuroendocrine tumors: a population-based analysis of epidemiology, metastatic presentation, and outcomes. Cancer 121: 589-597. Link: https://bit.ly/2MOHSo4

4. Ellis L, Shale MJ, Coleman MP (2010) Carcinoid tumors of the gastrointestinal tract: trends in incidence in England since 1971. Am J Gastroenterol 105: 2563-2569. Link: https://bit.ly/2AcG6xn

5. Caldarella A, Crocetti E, Paci E (2011) Distribution, incidence, and prognosis in neuroendocrine tumors: a population based study from a cancer registry. Pathol Oncol Res 17: 759-763. Link: https://bit.ly/2XwSArH

6. Ito T, Igarashi H, Nakamura K, Sasano H, Okusaka T, et al. (2015) Epidemiological trends of pancreatic and gastrointestinal neuroendocrine tumors in Japan: a nationwide survey analysis. J Gastroenterol 50: 58-64 Link: https://bit.ly/2zp13FE

7. Tsai HJ, Wu CC, Tsai CR, Lin SF, Chen LT, et al. (2013) The epidemiology of neuroendocrine tumors in Taiwan: a nation-wide cancer registry-based study. PLoS One 8: e62487. Link: https://bit.ly/2LY972u

8. Fraenkel M, Kim M, Faggiano A, de Herder WW, Valk GD, et al. (2014) Incidence of gastroenteropancreatic neuroendocrine tumours: a systematic review of the literature. Endocr Relat Cancer 21: R153-163. Link: https://bit.ly/2AY4HXb

9. Dasari A, Shen C, Halperin D, Zhao B, Zhou S, et al. (2017) Trends in the Incidence, Prevalence, and Survival Outcomes in Patients With Neuroendocrine Tumors in the United States. JAMA Oncol 3: 1335-1342. Link: https://bit.ly/2A64HnQ

10. Fraenkel M, Kim MK, Faggiano A, Valk GD (2012) Epidemiology of gastroenteropancreatic neuroendocrine tumours. Best Pract Res Clin Gastroenterol 26: 691-703. Link: https://bit.ly/36xLPKv

11. Mitry E, Baudin E, Ducreux M, Sabourin JC, Rufie P, et al. (1999) Treatment of poorly differentiated neuroendocrine tumours with etoposide and cisplatin. $\mathrm{Br}$ J Cancer 81: 1351-1355. Link: https://bit.ly/3d3npe9

12. van Essen M, Krenning EP, Kam BL, de Jong M, Valkema R, et al. (2009) Peptide receptor radionuclide therapy for endocrine tumors. Nat Rev Endocrinol 5 382-393. Link: https://bit.ly/2zp1U9k

13. Hofland LJ, Lamberts SW, van Hagen PM, Reubi JC, Schaeffer J, et al. (2003) Crucial role for somatostatin receptor subtype 2 in determining the uptake of [111/n-DTPA-D-Phe1] octreotide in somatostatin receptor-positive organs. $J$ Nucl Med 44: 1315-1321. Link: https://bit.ly/2B6uFlp

14. Ministerio de Salud del Gobierno de Chile (2019) PROTOCOLO 2019 Tratamiento con sunitinib o everolimus para personas con enfermedad progresiva de tumores neuroendocrinos pancreáticos. Departamento Evaluación de Tecnologías Sanitarias y Salud Basada en Evidencia. Link: https://bit.ly/2LYwfhv

15. Bodei L, Mueller-Brand J, Baum RP, Pavel ME, Horsch D, et al. (2013) The join IAEA, EANM, and SNMMI practical guidance on peptide receptor radionuclide therapy (PRRNT) in neuroendocrine tumours. Eur J Nucl Med Mol Imaging 40: 800-816. Link: https://bit.ly/2XyE1DY

16. Kwekkeboom DJ, de Herder WW, Kam BL, van Eijck $\mathrm{CH}$, van Essen $\mathrm{M}$, et al. (2008) Treatment with the radiolabeled somatostatin analog [177 Lu-DOTA

Citation: Amaral H, Pruzzo R, Fernández R, Kramer V, Ried CS, et al. (2020) Chilean experience using "Theranostics" for treating metastatic neuroendocrine tumors with [ ${ }^{177}$ Lu]Lu DOTA-TATE. Arch Clin Gastroenterol 6(2): 036-040. DOI: https://dx.doi.org/10.17352/2455-2283.000076 
0,Tyr3]octreotate: toxicity, efficacy, and survival. J Clin Oncol 26: 2124-2130. Link: https://bit.ly/3gra0i2

17. Ezziddin S, Opitz M, Attassi M, Biermann K, Sabet A, et al. (2011) Impact of the $\mathrm{Ki}-67$ proliferation index on response to peptide receptor radionuclide therapy. Eur J Nucl Med Mol Imaging 38: 459-466. Link: https://bit.ly/2TH8mzf

18. Kaltsas GA, Papadogias D, Makras P, Grossman AB (2005) Treatment of advanced neuroendocrine tumours with radiolabelled somatostatin analogues. Endocr Relat Cancer 12: 683-699. Link: https://bit.ly/3eim3wq

19. Ter-Minassian M, Chan JA, Hooshmand SM, Brais LK, Daskalova A, et al. (2013) Clinical presentation, recurrence, and survival in patients with neuroendocrine tumors: results from a prospective institutional database. Endocr Relat Cancer 20: 187-196. Link: https://bit.ly/2X3wY7y

20. Katz SC, Donkor C, Glasgow K, Pillarisetty VG, Gonen M, et al. (2010) T cell infiltrate and outcome following resection of intermediate-grade primary neuroendocrine tumours and liver metastases. HPB 12: 674-683. Link: https://bit.ly/2X233MK

21. Vikman S, Sommaggio R, De La Torre M, Oberg K, Essand M, et al. (2009) Midgut carcinoid patients display increased numbers of regulatory $T$ cells in peripheral blood with infiltration into tumor tissue. Acta Oncol 48: 391-400. Link: https://bit.ly/2LZnzaH

22. Maqsood MH, Tameez Ud Din A, Khan AH (2019) Neuroendocrine Tumor Therapy with Lutetium-177: A Literature Review. Cureus 11: e3986. Link: https://bit.ly/2zoa021
23. Pinto MP, Munoz Medel M, Carrillo D, Retamal IN, et al. (2019) Chilean Registry for Neuroendocrine Tumors: A Latin American Perspective. Horm Cancer 10: 3-10. Link: https://bit.ly/3c2G0Ga

24. O'Connor JM, Marmissolle F, Bestani C, Pesce V, Belli S, et al. (2014) Observational study of patients with gastroenteropancreatic and bronchial neuroendocrine tumors in Argentina: Results from the large database of a multidisciplinary group clinical multicenter study. Mol Clin Oncol 2: 673-684. Link: https://bit.ly/2X3f9p2

25. Younes RN (1992) Getne Neuroendocrine tumors: a registry of 1,000 patients. Rev Assoc Med Bras 54: 305-307. Link: https://bit.ly/2XuJFHs

26. Comaru-Schally AM, Schally AV (2005) A clinical overview of carcinoid tumors perspectives for improvement in treatment using peptide analogs (review). Int J Oncol 26: 301-309. Link: https://bit.ly/2AVF60C

27. Strosberg J, El-Haddad G, Wolin E, Hendifar A, Yao J, et al. (2017) Phase 3 Trial of (177)Lu-Dotatate for Midgut Neuroendocrine Tumors. N Engl J Med 376 125-135. Link: https://bit.ly/2TBy6go

28. Yao JC, Fazio N, Singh S, Buzzoni R, Carnaghi C, et al. (2016) Everolimus for the treatment of advanced, non-functional neuroendocrine tumours of the lung or gastrointestinal tract (RADIANT-4): a randomised, placebo-controlled, phase 3 study. Lancet 387: 968-977. Link: https://bit.ly/3daka4Y

29. Kim SJ, Pak K, Koo PJ, Kwak JJ, Chang S (2015) The efficacy of (177)Lulabelled peptide receptor radionuclide therapy in patients with neuroendocrine tumours: a meta-analysis. Eur J Nucl Med Mol Imaging 42: 1964-1970. Link: https://bit.ly/2X2f1pD

\section{Discover a bigger Impact and Visibility of your article publication with}

\section{Peertechz Publications}

\author{
Highlights \\ * Signatory publisher of ORCID \\ * Signatory Publisher of DORA (San Francisco Declaration on Research Assessment) \\ * Articles archived in worlds' renowned service providers such as Portico, CNKI, AGRIS \\ TDNet, Base (Bielefeld University Library), CrossRef, Scilit, J-Gate etc. \\ * Journals indexed in ICMJE, SHERPA/ROMEO, Google Scholar etc. \\ * OAI-PMH (Open Archives Initiative Protocol for Metadata Harvesting) \\ * Dedicated Editorial Board for every journal \\ * Accurate and rapid peer-review process \\ * Increased citations of published articles through promotions \\ - Reduced timeline for article publication \\ Submit your articles and experience a new surge in publication services \\ (https://www.peertechz.com/submission).
}

Peertechz journals wishes everlasting success in your every endeavours.

Copyright: @ 2020 Amaral H, et al. This is an open-access article distributed under the terms of the Creative Commons Attribution License, which permits unrestricted use distribution, and r eproduction in any medium, provided the original author and source are credited.

Citation: Amaral H, Pruzzo R, Fernández R, Kramer V, Ried CS, et al. (2020) Chilean experience using "Theranostics" for treating metastatic neuroendocrine tumors with [177Lu]Lu DOTA-TATE. Arch Clin Gastroenterol 6(2): 036-040. DOI: https://dx.doi.org/10.17352/2455-2283.000076 